\title{
Computer Tool for Sizing and Economic Assessment of Grid-Connected Photovoltaic System
}

\author{
Arnold Ferney Torres-Ome ${ }^{1}$, Ana Lucía Paque-Salazar ${ }^{1}$, Fernand Diaz-Franco $^{1} \&$ July Steffany González-López ${ }^{1}$ \\ ${ }^{1}$ College of Engineering, University Corporation of Huila, Neiva, Colombia \\ Correspondence: Arnold Ferney Torres Ome, College of Engineering, University Corporation of Huila, Calle 8 \\ No. 32 -49, Neiva, Colombia. E-mail: arnold.torres@corhuila.edu.co
}

Received: June 18, 2018

doi:10.5539/jsd.v11n5p137
Accepted: August 10, $2018 \quad$ Online Published: September 28, 2018

URL: https://doi.org/10.5539/jsd.v11n5p137

\begin{abstract}
Thanks to the location close to the Equator line, Colombia offers an advantage location for solar applications. This is the case of Neiva, a city located in the south of Colombia where the average temperature and irradiance are $31{ }^{\circ} \mathrm{C}$ and $4 \mathrm{~kW} / \mathrm{m}^{2}$ respectively. This paper describes the development of an investment payback solar calculator (PSC) software for residential and commercial PV solar applications in Neiva. The PSC uses both the average solar energy and the electricity prices to estimate the rate of return on investment, the payback period (PBP), the net present value (NPV) as well as the environmental impact. The PCS software is then evaluated using a historical and statistical information from NASA, adjusted with the results of a small scale $1 \mathrm{~kW}$ grid connected PV system production. The results show that the PCS software can satisfactorily indicate the PV system size and perform an economic evaluation of the system to be implemented. The results obtained using the application developed were compared to two commercially available software Sunny Design and HOMER. The NPV and the PBP values showed that the proposed application results are like those delivered by the commercial software. Furthermore, the economic evaluation given by the developed tool uses additional information which makes it more accurate in countries where socioeconomic stratum is presented.
\end{abstract}

Keywords: PV, energy cost modelling, Renewable energy

\section{Introduction}

According to World Bank data, $80 \%$ of the energy consumed around the world comes from traditional energy resources like oil, coal and gas (Portafolio, 2016). This scenario causes negative impacts that governments need to address. The principal issue is the negative environmental impact to the planet that produces an increment on the global temperature caused by higher concentration of carbon dioxide in the atmosphere. Therefore, several projects are being implemented to generate power from renewable resources like solar energy.

Several contributing countries of air pollution have been developing policies and agreement related to $\mathrm{CO}_{2}$ emission reduction and promoting carbon capture. In that way, initiatives such as applications with no-conventional energy resources are increasing in last years with the aim of reducing greenhouse gases. Countries around the world are creating new policies to reduce conventional energy consumption (Jackson, 2011; Pickard, 2016) and satisfy Kyoto agreement (Císcar \& Soria, 2002). For instance, Scotland created policies that includes climate target for $\mathrm{CO}_{2}$ reduction (Anandarajah \& McDowall, 2012), Greece introduced a renewable energy policy based on electricity consumption to integrate no conventional resources in the national energy market (Economou, 2011). On the other hand, India implemented different policies to accelerate the growth of renewable energy deployment(Mahesh \& Shoba Jasmin, 2013). Other countries in South America are adding more programs such as feed in tariff (Economou, 2011; Mahesh et al.,2013;Solangi et al.,2011; Chowdhury et al.,2014; del rio gonzález et al., 2008), tax incentives (Balcombe et al., 2013; Chowdhury et al., 2014; Jackson, 2011; Jimenez, Franco, \& Dyner, 2016; Radomes \& Arango, 2015) and net metering system (Eid, Reneses Guillén, Frías Marín, \& Hakvoort, 2014; Schelly, Louie, \& Pearce, 2017; Westwood \& Hopwood, 2010; Wiedman \& Beach, 2013) to pursuit the diffusion of renewable technology.

Nowadays, solar energy represents the second most widely used non-conventional renewable source around the world, with a production between $0.85 \%$ and $1 \%$ of the world's electricity demand(UPME \& BID, 2015). Although Colombia's location offers advantages for solar applications, $78 \%$ of the primary energy resources comes from fossil fuel(Murcia et al., 2015). 
The generation capacity of Colombia national interconnected system is mainly hydroelectric systems with $64 \%$, followed by thermoelectric plants with $31 \%$, and the remaining it is shared by minor plants, such as small hydroelectric, wind power plants and PV power plants(UPME, 2009).

The Colombian electric power demand has had a steady growth in the last decade, with an average of $2.8 \%$ each year (UPME,2015). For that reason, the country needs to accelerate the development of technologies for energy conversion from renewable resources; to supply the required demands.

Often the most difficult question to answer is whether it makes financial sense to go forward with the project. Common questions related to these projects are: What would be a suitable size? How long would it take to recover the cost of investment? What is the impact of tax incentives on the annual cash flow? In the literature, several authors have proposed software algorithms to calculate technical sizing of PV systems(Anwari, Dom, \& Rashid, 2011; Chikh, Mahrane, \& Bouachri, 2011; Guerrero-Rodríguez, Rey-Boué, \& Reyes-Archundia, 2017; Satapathy, Dhar, \& Dash, 2017; Shukla, Sudhakar, \& Baredar, 2016; Skunpong \& Plangklang, 2011); whereas the economic impacts have been reported in(Bilir \& Yildirim, 2017; Davidson \& Steinberg, 2013; Grande, Yahyaoui, \& Gómez, 2018; Hoen et al., 2017). Other works utilize an optimization procedure to adjust the size of the PV installation based on the economic impact (Anandarajah \& McDowall, 2012; Bianchini, Guzzini, Pellegrini, \& Saccani, 2017; Shukla et al., 2016).

This study describes the development of a software tool for the sizing and economic evaluation of a grid-tied PV system in residential applications. This paper is organized as follows. In Section 2, the irradiation data, energy produced and tariff scheme for the city of Neiva are introduced, and it is followed by the description of the computer tool developed. In Section 3, the results are presented for solar Potential, PV energy generation, trend electricity price and PCS results. Then is compared with two commercially available software-SUNNY DESIGN and HOMER - and the economic impact of the same installation in two different countries is estimated. Finally, the concluding remarks are addressed in Section 5.

\section{Method}

In this chapter we describe the data introduced in the tool for sizing and economic evaluation of PV systems in the city of Neiva, considering the average number of hours of sunlight consulted at NASA and the one experimentally obtained at Neiva. In addition, the cost of energy by socioeconomic status in the city is considered.

\subsection{Solar Irradiance Data}

The solar irradiance data for the city of Neiva was obtained from the National Aeronautics and Space Administration (NASA). To improve the accuracy and to get a clear understanding of the patterns, the data used goes from 2012 to 2016. The NASA records are contrasted with ground based meteorological stations that registered solar radiation, ambient temperature, and the wind speed. The information is also compared with a PV system that registered the sun hours for 1 year in the location of interest.

\subsection{Electrical PV Production Data}

The energy generated by PV installations can be calculated using the PV power capacity and the standard sun hours (taken from meteorology databases(REN21, 2015). However, this historical data might present some variations compared to recent weather station records. Moreover, to better corroborate the results, a small scale 1 $\mathrm{kWp}$ grid-tied PV system was installed in the city of interest.

The installed grid-tied system (Figure 1) is composed by four (4) modules $260 \mathrm{Wp}-$ Canadian Solar - a $1.0 \mathrm{kWp}$ SMA single-phase inverter. A current sensor meter is also installed for energy measurement and it is connected to a Raspberry Pi that sends the current data to a web server (10 min sampling time).

\subsection{Electricity Tariff Information}

First, an evaluation of the electricity price trend during the last two years was made to obtain the return of investment for a PV system located in Neiva. In Colombia, the compensation payment for renewable energy depends on social stratification; therefore, this parameter is also considered during the statistical analyse. Every socioeconomic stratum includes taxes incentives, and these are taken in account on the simulator algorithm.

\subsection{Calculation}

\subsubsection{Sizing and Technical Evaluation}

To meet energy requirements of consumer, the grid connected solar PV system was design based on electrical average consumption for the last 2 years. 

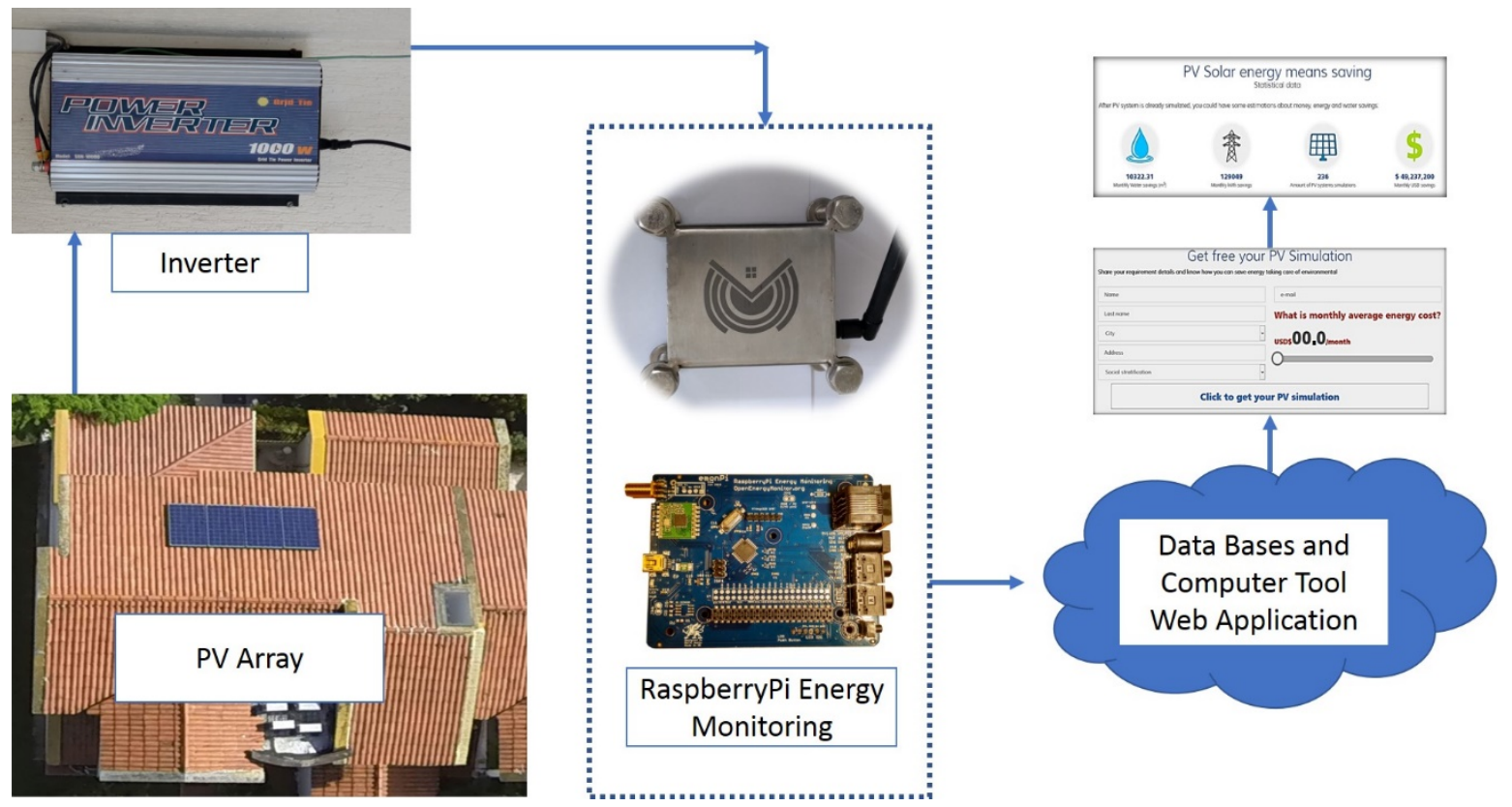

Figure 1. Grid-tied system

First, the amount of PV modules can be calculated with the average electricity consumption, solar irradiance available, and maximum power generation of the polycrystalline module. It is important to note that the PV efficiency of the PV modules used in this setup is $16.16 \%$. The second step is to define the inverter nominal capacity based on the PV array.

Most of the residential facilities have a similar daily demand profile, the solar power demand could be the $25 \%$ of the total diary energy consumption(Franco, Velásquez, \& Olaya, 2008), reason why the self-consumption percentage was chosen as $25 \%$ in the economic evaluation of the solar calculator.

\subsubsection{Economic Evaluation}

For the financial PV system evaluation, some economic parameters must be considered as the electricity cost growth. It includes a 7\% inflation rate which is a conservative scenario considering the recent raise of electricity cost in Neiva that has reached $8-10 \%$ in the past 6 months. In addition, the PV panel degradation is a crucial factor for the economic evaluation. The annual PV panel degradation rate taken was $0.6 \%$ as it is shown in the PV panel datasheet conditions.

Another fundamental parameter is the installed Watt price, which allows determining the PV system cost. There are two types of costs for PV system: Hard cost and soft cost. The first is related to the highest costs like solar panels, inverter and other electrical components. The second is related to the price installation. In Colombia, the hard costs are the same as worldwide prices (high quantity importations), whereas the soft costs are cheaper compared to developed countries. Therefore, \$1.8 USD is considered in the algorithm as the Watt installed price.

\subsubsection{Cash Flow and Savings}

With input data, the simulator estimates the numbers of panels, power energy, inverter capacity and the total cost of the energy system. The cash flow is determined by the period of target PV run life (25 years), where the initial cost is the value for the year when it is equal to zero. The mathematical expression is presented in eq. 1(Wiley\&Sons, 2016).

Where:

$$
\mathrm{F}_{\mathrm{t}}=\mathrm{E}_{\mathrm{P}} * \eta_{\mathrm{red}-\mathrm{FV}} * \mathrm{C}_{\mathrm{kwh}} *(1+\mathrm{inf})^{\mathrm{t}}
$$

$E_{P}$ : Annual energy production to PV system

$\eta_{\text {red-FV }}$ : Decreasing in performance PV panel. It is represented by: $\eta_{\text {red-FV }}=1-\operatorname{dec}_{F V}$

$\operatorname{dec}_{F V}$ : PV panel degradation (0.6\%)

$C_{k w h}$ : Cost of energy (USD/kWh) 
inf: The energy inflation rate $(7 \%)$

$t$ : Time in years

The next step is to calculate the cumulative cash flow which can be calculated following the eq. 2 .

$$
F_{t_{a c}}=\sum_{i=0}^{n} F_{t_{i}}
$$

Where:

$\mathrm{n}=25$ years (Target $\mathrm{PV}$ module)

$i=$ initial year,

Where $i=0$ then cash flow is equal to $-\mathrm{Ci}, \mathrm{Ci}$ is the cost of the system.

The PBP is determined by an iterative cycle where the main aim is to find the year when the cumulative cash flow is positive. For that, the simulator creates a matrix with the values for 25 years, the values of decreasing in performance PV panel, cash flow and cumulative cash flow. Finally, the algorithm considers interpolations when is necessary.

\subsubsection{Investment Returns}

The evaluation of investment return was measured by the rate of return on investment (IRR) and the net present value (NPV). In this case, the investment is the total cost of the energy system. These variables have related each other to the eq. 3 (Wiley\&Sons, 2016).

$$
N P V=-C_{i}+\sum_{t=1}^{n} \frac{F_{t}}{(1+I R R)^{t}}
$$

Where:

$V P N$ : The net present value

$C_{i}$ : Initial cost, Total cost of system

$F_{t}$ : Cash flow at time $\mathrm{t}$

$I R R$ : The rate of return on investment

$t$ : Time in years

$n$ : Target PV module, 25 years

To estimate the value of IRR is common to use an approximation of Schneider based on binomial theorem as it could be seen in the eq. 4 (Wiley\&Sons, 2016)

$$
-C_{i}+\sum_{t=1}^{n} \frac{F_{t}}{(1+I R R)^{t}}=0
$$

To estimate the IRR value, an option is using a numerical solution with methods available in investigations on this field.

The process followed in the algorithm is to give values for IRR initial, the rate of rising and accuracy. In the same way, it will calculate values and difference between them. The procedure is performed by iterative cycle until the accuracy will be less than $1 \times 10^{-5}$. Finally, the NPV value is calculated by eq. 3 .

\subsection{Software Algorithm}

A beta version simulator was developed to calculate the size of PV System, costs and IRR, the PBP and the NPV for residential and commercial facilities, based upon user inputs. Flow chart diagram is shown in Figure 2.

The steps for calculation were coding in PHP programming language for sizing and economic evaluation for the grid-tied system. To log in, the application has a user module with easy access in, where the users have the capability to bring their average cost of the electricity bill and their social stratification tier as inputs to determine 


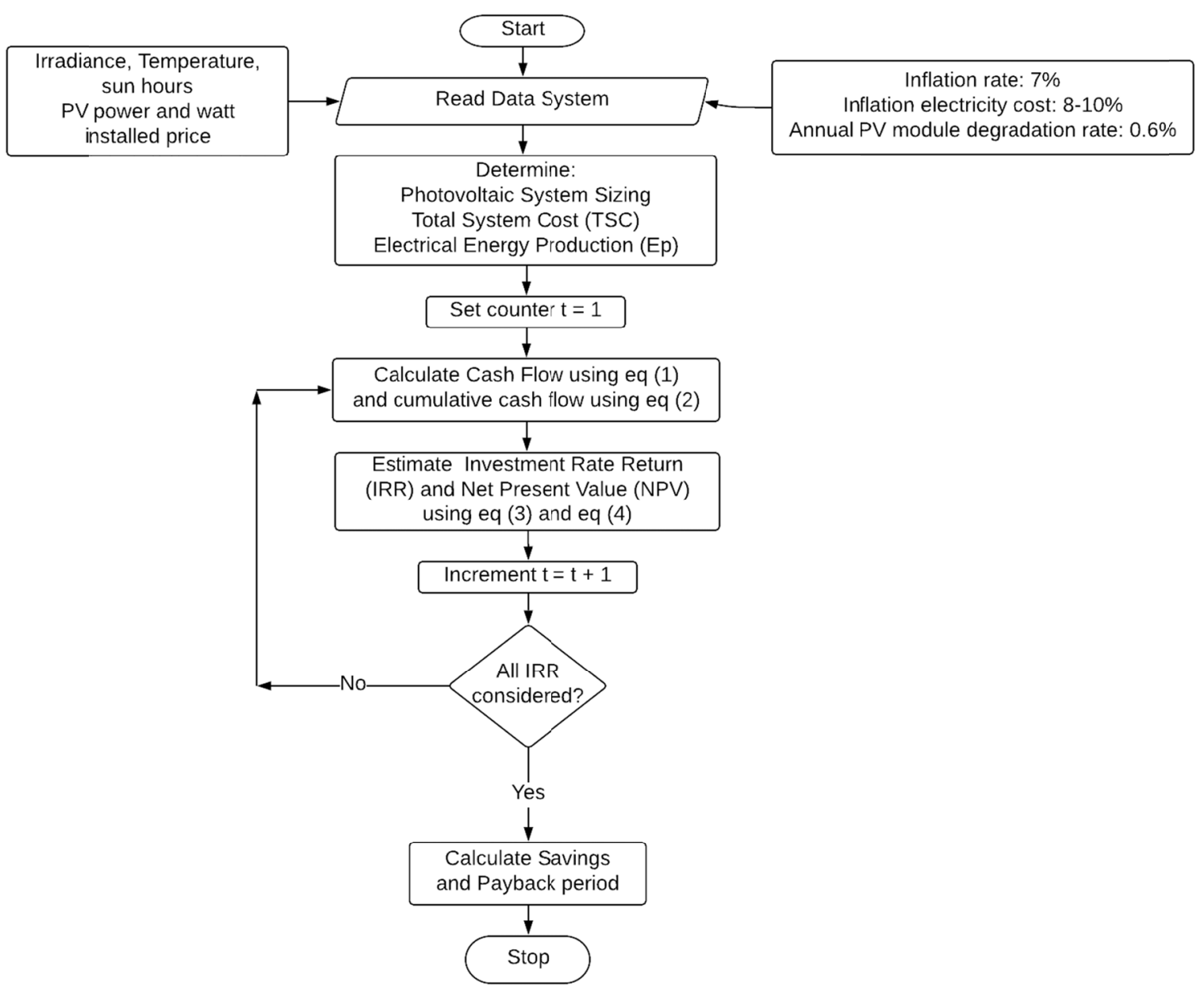

Figure 2. Flow chart diagram for software algorithm

the size and financial calculations for the PV system.

The web application offers to the user an easy tool to know the PV size, cost and financial performance. The user's data is sent to the simulator, where is taken as initial parameters to determine the economic analysis according to the administrator input, PV coverage percentage (self-consumption), inflation rate, annual panel degradation rate and the diary energy PV panel generation. All these settings are based on previous studies related to the current energy and economic background.

The web application has an interface and it is shown in Figure 3, where the user must fill out the information to estimate the PV System.

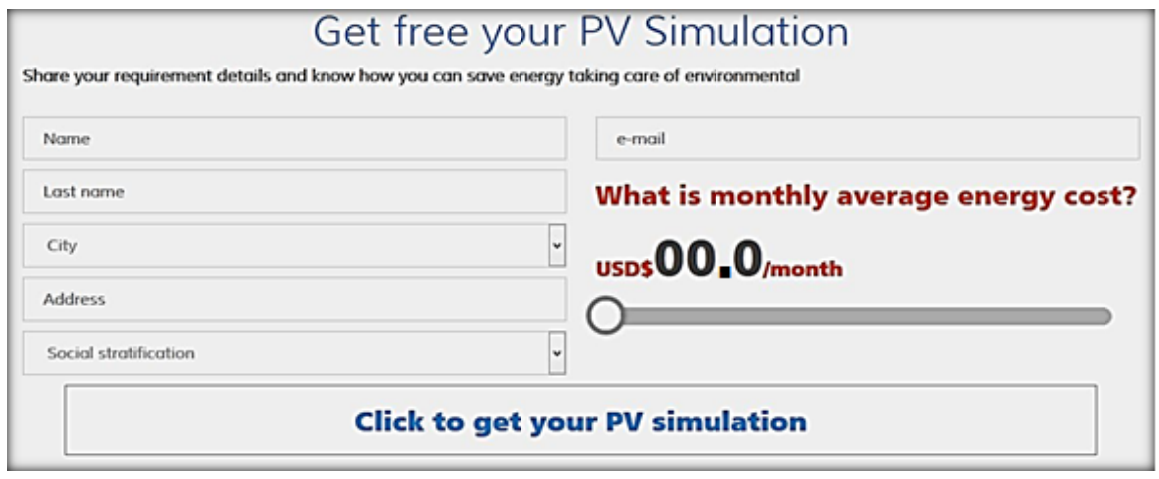

Figure 3. Calculation section 


\section{Results}

\subsection{Solar Potential}

The solar resource was obtained based on data from NASA(Nasa, 2011) for the place of interest Figure 4 shows the solar radiation for a year where average value is near to $3.9 \mathrm{~kW} / \mathrm{m}^{2}$.

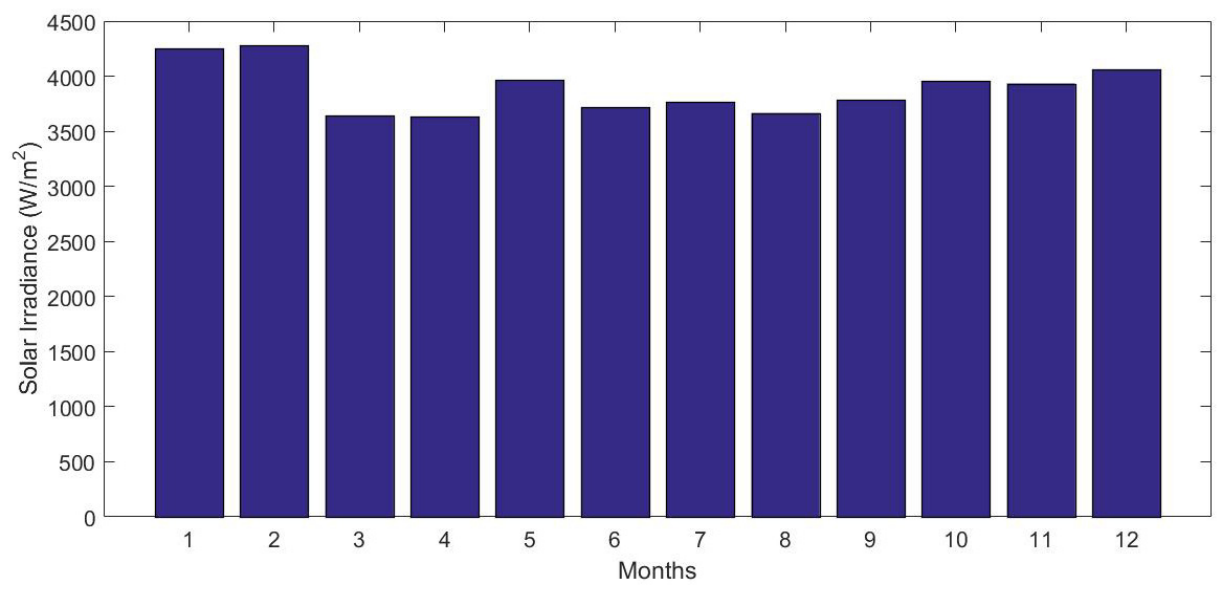

Figure 4. Solar Irradiance for Neiva, Colombia. Data from NASA (Nasa, 2011)

\subsection{Energy Generation}

The data was measured and recorded from February 2015 to February 2016. The results obtained for July are shown in Figure 5 which delivers an average power generation of $4.43 \mathrm{kWh} /$ day for the installed PV system. This information is used to determine the PV system size into the simulator, and it is updated every month with the monthly electricity cost company report.

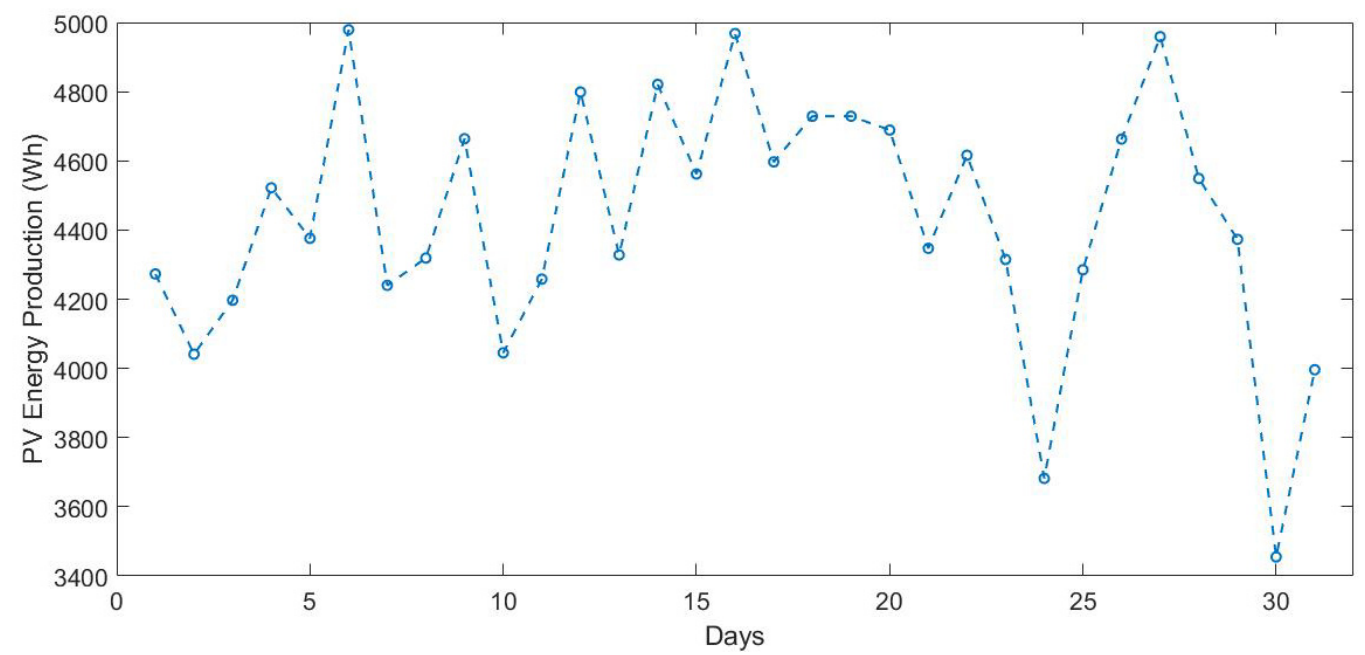

Figure 5. Energy production. July 2016

\subsection{Trend Electricity Price}

Every socioeconomic stratum has included the respective subsidies, contributions and street lightning rate, which is considered in the algorithm. Table 1 shows the electricity cost per social stratification. 
Table 1. Electricity cost per social stratification.

\begin{tabular}{cc}
\hline Socioeconomic Stratum & $\begin{array}{c}\text { Average electricity cost } \\
\text { (cent USD \$/kWh) }\end{array}$ \\
\hline 1 & 7 \\
2 & 8 \\
3 & 14 \\
4 & 15 \\
$5-6$ & 18 \\
\hline
\end{tabular}

\subsection{Software}

The simulation results show the PV system size with the number of PV modules and the rooftop area required. Additionally, it shows the cost of the system, the economic evaluations, the IRR, the PBP, and the NPV. The information is studied by the user to determine the system viability. The environmental impact is shown with some statistics that reflect the benefits in developing the PV system.

\subsubsection{Simulation Results}

The proposed algorithm is tested for a residential case with socioeconomic stratum 3 in the city of Neiva Colombia as it can be seen in Figure 6.

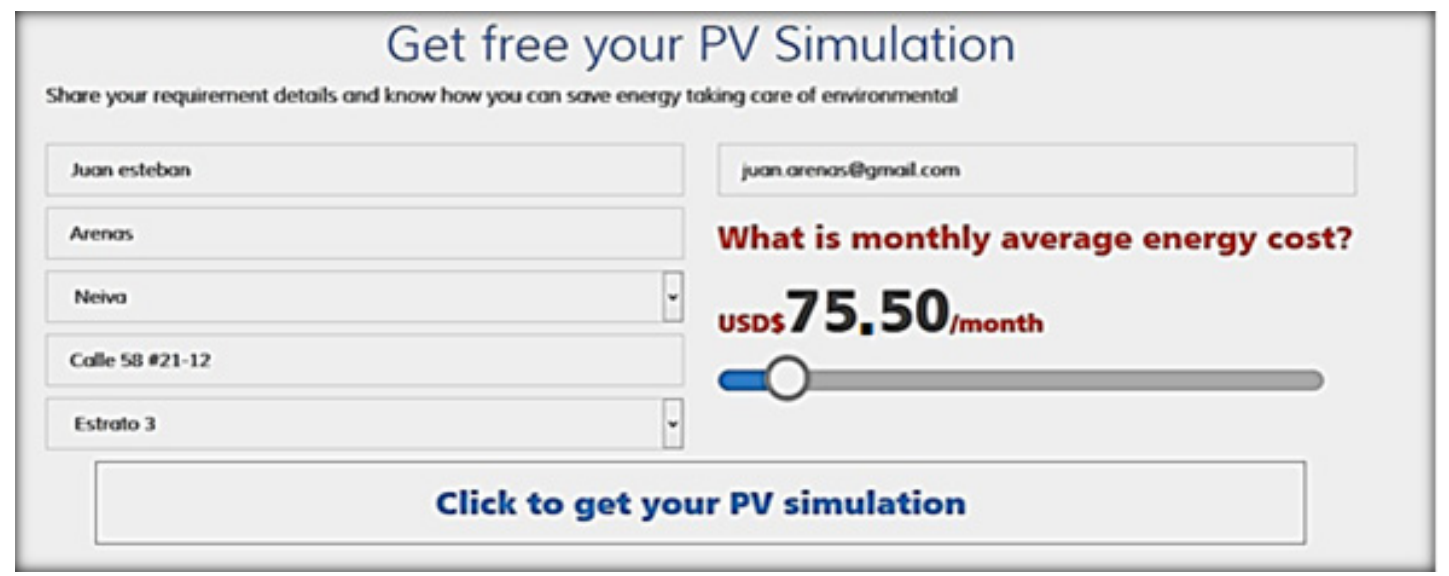

Figure 6. User data interface

The results show the system specifications: size, number of panels, rooftop area and these are shown in Figure 7 whereas Figure 8 and Figure 8 illustrate the economic evaluation results and the environmental impact during the life cycle of the system ( 25 years). 


\section{SOLAR REPORT \\ ENERGY POTENTIAL \\ Juan esteban Arenas \\ Neiva \\ Calle 58 \# 21-12}

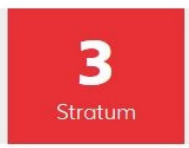

Techinical Data

The following information is the result of financial analysis performed by the Computer Tool.

Number of modules

Total Power to Install (kW)

Module Power (W)

Module Area $\left(\mathrm{m}^{2}\right)$

Total System Area $\left(\mathrm{m}^{2}\right)$

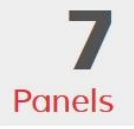

16

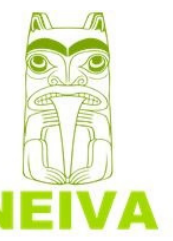

Panels

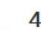

250

1.6

20.8

Figure 7. PV system specification results

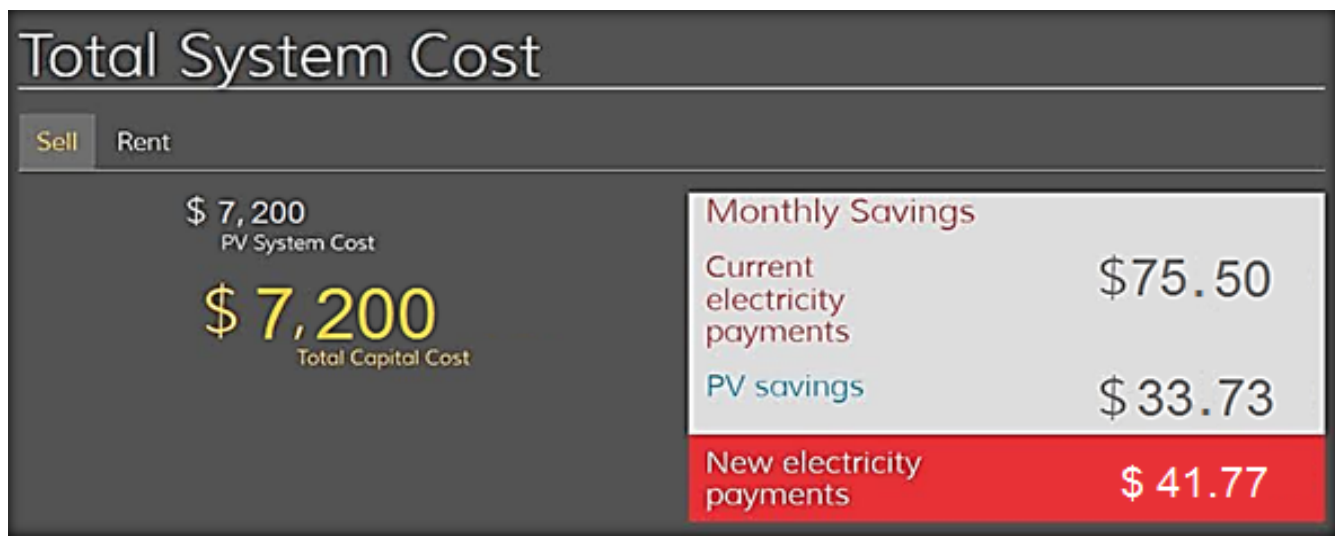

Figure 8. Economic evaluation results

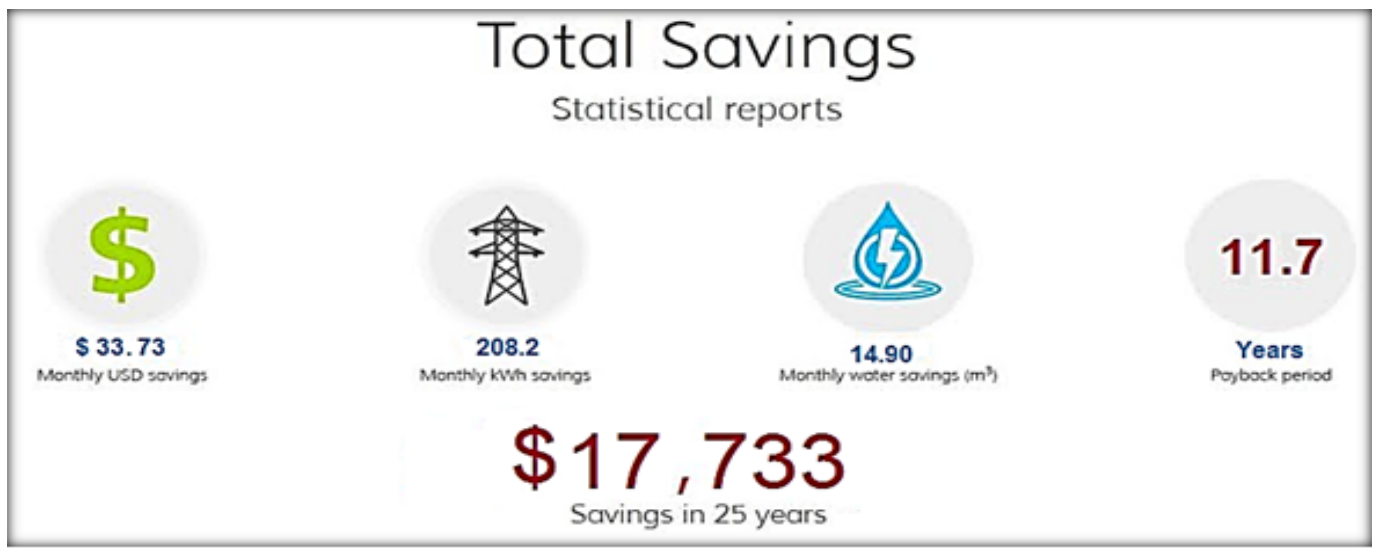

Figure 9. Environmental and saving results

The PCS also provides the cumulative cash flow to determine the economic projection as it is shown in Figure 10. The PBP analysis shows that in the $11^{\text {th }}$ year, the initial investment is recovered and in the $25^{\text {th }}$ year, the cumulative savings is around $\$ 17,733$ USD. 


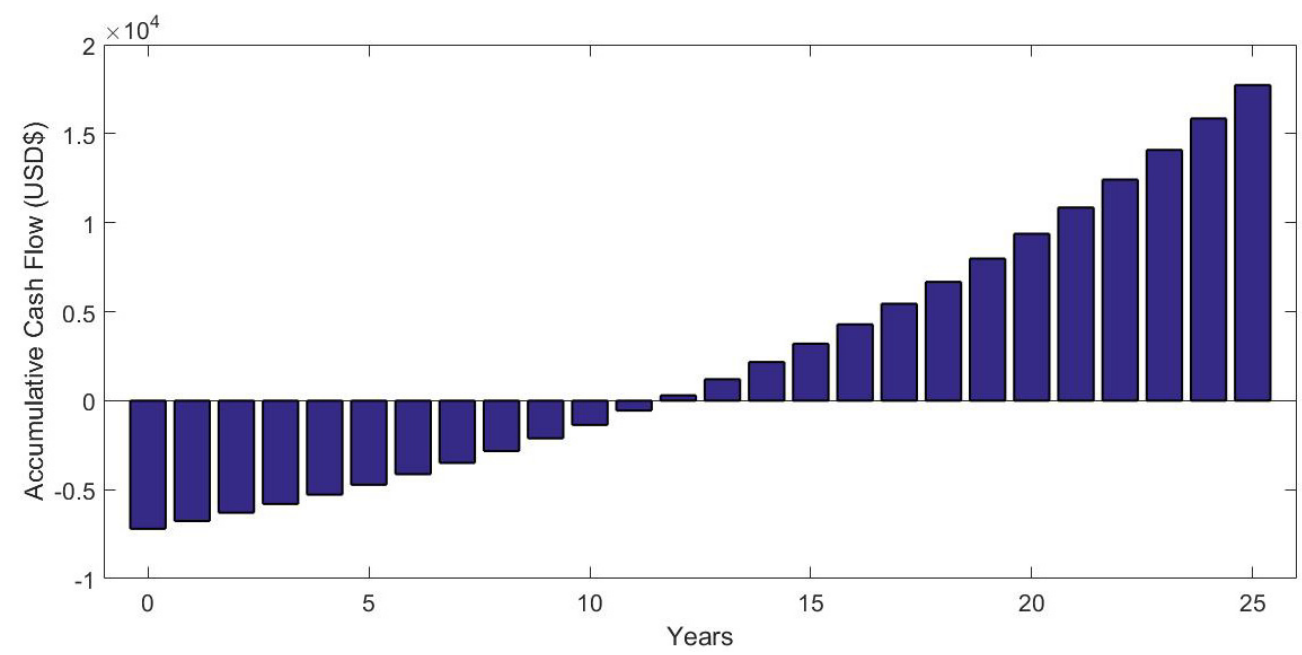

Figure 10. PV system cumulative cash flow

The web application was tested for different residential conditions and the payback period varies between 15 and 7 years according to the social stratification. In the case of the upper stratum, the return on investment is faster because the cost of the electricity price is higher.

\section{Discussion}

In order to compare the results obtained by the proposed PCS method, two commercial software- Sunny Design and HOMER - are used to evaluate the algorithm operation. The total installed capacity of the system of $4 \mathrm{~kW}$ to supply monthly electrical energy consumption was evaluated.

The meteorological characteristics of Neiva; the energy requirements of the house, the energy price and the configuration of PV system, among other information are introduced in the two software previously mentioned. The economic result is shown for both simulators in Figure 11. The initial cost is the biggest one in HOMER series compared with other two. It indicates initial investment is higher than others due to hard cost of equipment considered for that software.

On the other hand, the PBP value illustrates 10 years for Sunny design, 12 years in PCS and 13 years in HOMER. The target life time presents effective savings with values 19000, 17000 and 16000 dollars for Sunny Design, PCS and HOMER respectively. The Upper one is because of the net metering is consider for the cases when the electrical generation is higher than consumption, providing additional saving by the electrical energy injected to the grid. The others don't consider than option causing Sunny Design simulation has more savings and lower Payback Period.

These economic analyses show that PCS, a software adjusted to socioeconomic stratum tariff give a representative evaluation to determine PV System feasibility to perform in Neiva.

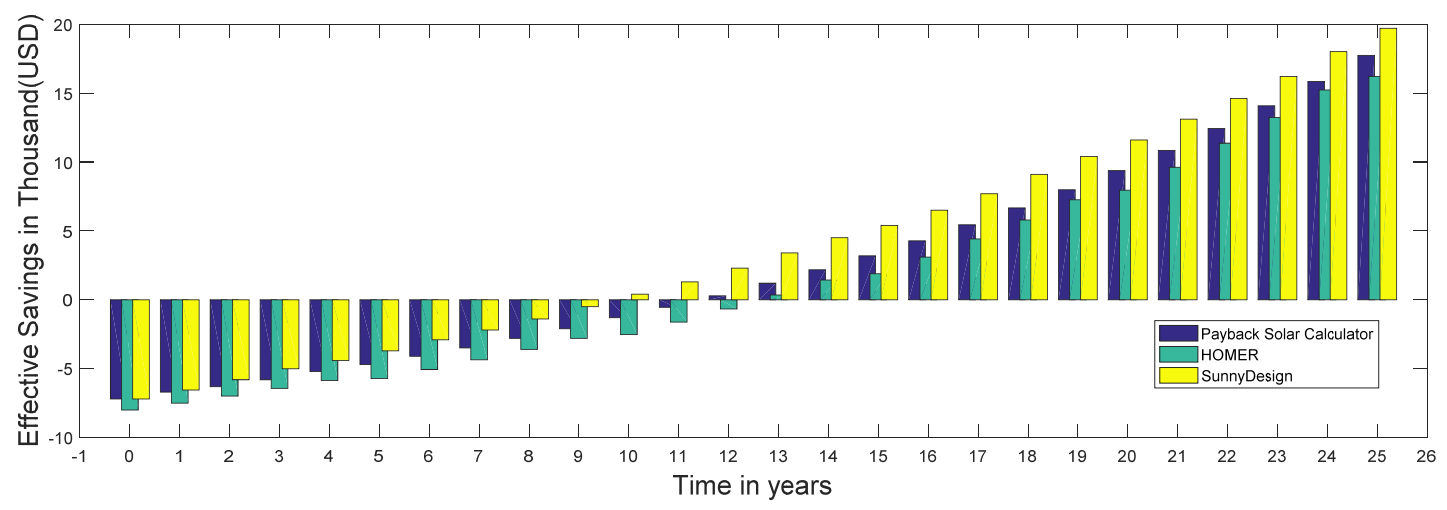

Figure 11. Effective savings for PCS, HOMER and Sunny Design 


\subsection{Comparations with Case Study in Norway}

The PV system considered for comparation is a study made in the Norwegian University of Life Sciences-Norway (Adaramola, 2015) for a building with total installed capacity of the system of $2.0 \mathrm{~kW}$. The total annual energy production estimated was $1927.7 \mathrm{kWh}$ and total investment was taken as US\$6930. Financial assessment performed for project life of 15 years determined cost of electricity in US\$ $0.333 / \mathrm{kWh}$. Payback period showed 11 years to recover the investment and total savings obtained in US $\$ 7075$ by the same time. For this economic analysis, the interest rate is taken as $6.0 \%$ while the inflation rate of $2.0 \%$ is used.

The same installed system was evaluated in PCS software. It found initial capital cost in US\$4000, output electrical production in $1424 \mathrm{kWh}$ per year, PBP value of 8 years and effective savings in US\$5904. In this study case, the cost of energy calculated varies between US $\$ 0.16$ to US $\$ 0.18 / \mathrm{kWh}$. Savings differences in both cases is due to interest rate and inflation rate; which in Neiva city is higher than Norway, $10 \%$ and $7 \%$ respectively.

\section{Conclusions}

In this study is proposed a Payback Calculator Software (PCS), an application to economic assessment of grid tied PV system for residential applications. The algorithm performed is composed by a procedure that include user's socioeconomic stratum in the cost of electrical energy. Additionally, the computer tool takes in account production data of $1 \mathrm{~kW}$ PV system installed that makes results more accurate. The PCS is compared with other two (2) commercial software to show the reliability on its results.

\section{Acknowledgments}

The authors would like to thank SUNNYAPP and University Corporation of Huila for providing the infrastructure, laboratories facilities, and the research resources.

\section{References}

Adaramola, M. S. (2015). Techno-economic analysis of a $2.1 \mathrm{~kW}$ rooftop photovoltaic-grid-tied system based on actual performance. Energy Conversion and Management, 101, 85-93. https://doi.org/10.1016/j.enconman.2015.05.038

Agterbosch, S., Meertens, R. M., \& Vermeulen, W. J. V. (2009). The relative importance of social and institutional conditions in the planning of wind power projects. Renewable and Sustainable Energy Reviews, 13(2), 393-405. https://doi.org/10.1016/j.rser.2007.10.010

Anandarajah, G., \& McDowall, W. (2012). What are the costs of Scotland's climate and renewable policies? Energy Policy, 50, 773-783. https://doi.org/10.1016/j.enpol.2012.08.027

Anwari, M., Dom, M. M., \& Rashid, M. I. M. (2011). Small scale PV monitoring system software design. Energy Procedia, 12, 586-592. https://doi.org/10.1016/j.egypro.2011.10.079

Balcombe, P., Rigby, D., \& Azapagic, A. (2013). Motivations and barriers associated with adopting microgeneration energy technologies in the UK. Renewable and Sustainable Energy Reviews, 22, 655-666. https://doi.org/10.1016/j.rser.2013.02.012

Bianchini, A., Guzzini, A., Pellegrini, M., \& Saccani, C. (2017). Photovoltaic/thermal (PV/T) solar system: Experimental measurements, performance analysis and economic assessment. Renewable Energy, 111, 543555. https://doi.org/10.1016/j.renene.2017.04.051

Bilir, L., \& Yildirim, N. (2017). Photovoltaic system assessment for a school building. International Journal of Hydrogen Energy, 42(28), 17856-17868. https://doi.org/10.1016/j.ijhydene.2017.02.122

Chikh, M., Mahrane, A., \& Bouachri, F. (2011). PVSST 1.0 sizing and simulation tool for PV systems. Energy Procedia, 6, 75-84. https://doi.org/10.1016/j.egypro.2011.05.009

Chowdhury, S., Sumita, U., Islam, A., \& Bedja, I. (2014). Importance of policy for energy system transformation: Diffusion of PV technology in Japan and Germany. Energy Policy, 68, 285-293. https://doi.org/10.1016/j.enpol.2014.01.023

Císcar, J. C., \& Soria, A. (2002). Prospective analysis of beyond Kyoto climate policy: A sequential game framework. Energy Policy, 30(15), 1327-1335. https://doi.org/10.1016/S0301-4215(02)00025-3

Davidson, C., \& Steinberg, D. (2013). Evaluating the impact of third-party price reporting and other drivers on residential photovoltaic price estimates. Energy Policy, 62, 752-761. https://doi.org/10.1016/j.enpol.2013.07.112

del Río González, P. (2008). Ten years of renewable electricity policies in Spain: An analysis of successive 
feed-in tariff reforms. Energy Policy, 36(8), 2907-2919. https://doi.org/10.1016/j.enpol.2008.03.025

Economou, A. (2011). Photovoltaic systems in school units of Greece and their consequences. Renewable and Sustainable Energy Reviews, 15(1), 881-885. https://doi.org/10.1016/j.rser.2010.09.028

Eid, C., Reneses Guillén, J., Frías Marín, P., \& Hakvoort, R. (2014). The economic effect of electricity net-metering with solar PV: Consequences for network cost recovery, cross subsidies and policy objectives. Energy Policy, 75, 244-254. https://doi.org/10.1016/j.enpol.2014.09.011

Franco, C. J., Velásquez, J. D., \& Olaya, I. (2008). Caracterización de la demanda mensual de electricidad en Colombia usando un modelo de componentes no observables. Cuadernos de Administración, 21, 235. Retrieved from http://www.scielo.org.co/pdf/cadm/v21n36/v21n36a10.pdf

Grande, L. S. A., Yahyaoui, I., \& Gómez, S. A. (2018). Energetic, economic and environmental viability of off-grid PV-BESS for charging electric vehicles: Case study of Spain. Sustainable Cities and Society, 37, 519-529. https://doi.org/10.1016/j.scs.2017.12.009

Guerrero-Rodríguez, N. F., Rey-Boué, A. B., \& Reyes-Archundia, E. (2017). Overview and comparative study of two control strategies used in 3-phase grid-connected inverters for renewable systems. Renewable Energy Focus, 19-20(June), 75-89. https://doi.org/10.1016/j.ref.2017.05.007

Hoen, B., Adomatis, S., Jackson, T., Graff-Zivin, J., Thayer, M., Klise, G. T., \& Wiser, R. (2017). Multi-state residential transaction estimates of solar photovoltaic system premiums. Renewable Energy Focus, 19 20(June), 90-103. https://doi.org/10.1016/j.ref.2017.05.006

Jackson, F. (2011). Scaling clean energy innovation: Clean technology is one of the great global opportunities of the 21st century, but how is technology innovation being harnessed? Renewable Energy Focus, 12(3), 5661. https://doi.org/10.1016/S1755-0084(11)70065-5

Jimenez, M., Franco, C. J., \& Dyner, I. (2016). Diffusion of renewable energy technologies: The need for policy in Colombia. Energy, 111, 818-829. https://doi.org/10.1016/j.energy.2016.06.051

Mahesh, A., \& Shoba Jasmin, K. S. (2013). Role of renewable energy investment in India: An alternative to CO2mitigation. Renewable and Sustainable Energy Reviews, 26, 414-424. https://doi.org/10.1016/j.rser.2013.05.069

Murcia, H. R., Merino, L., UPME, \& BID. (2015). Integración de las energías renovables no convencionales en Colombia. Revista de Ingeniería, 28, 188. https://doi.org/ISSN. 0121-4993

Nasa. (2011). Surface meteorology and Solar Energy. Retrieved from http://eosweb.larc.nasa.gov/sse/

Pickard, M. (2016). Global investment in renewable energy projects: How the whole world is jumping on the renewables bandwagon. Renewable Energy Focus, 17(6), 229-230. https://doi.org/10.1016/j.ref.2016.10.008

Portafolio. (2016). Energías renovables, la apuesta que debe hacer el país. Revista Portafolio. Retrieved from $\mathrm{http}: / / \mathrm{www}$.portafolio.co/innovacion/energias-renovables-en-colombia-502061

Radomes, A. A., \& Arango, S. (2015). Renewable energy technology diffusion: An analysis of photovoltaic-system support schemes in Medellín, Colombia. Journal of Cleaner Production, 92, 152-161. https://doi.org/10.1016/j.jclepro.2014.12.090

REN21. (2015). Renewables 2015-Global status report. REN21 Renewables (Vol. 4). https://doi.org/10.1016/0267-3649(88)90030-1

Satapathy, P., Dhar, S., \& Dash, P. K. (2017). An evolutionary online sequential extreme learning machine for maximum power point tracking and control in multi-photovoltaic microgrid system. Renewable Energy Focus, 21(October), 33-53. https://doi.org/10.1016/j.ref.2017.08.001

Schelly, C., Louie, E. P., \& Pearce, J. M. (2017). Examining interconnection and net metering policy for distributed generation in the United States. Renewable Energy Focus, 22-23(December), 10-19. https://doi.org/10.1016/j.ref.2017.09.002

Shukla, A. K., Sudhakar, K., \& Baredar, P. (2016). Design, simulation and economic analysis of standalone roof top solar PV system in India. Solar Energy, 136, 437-449. https://doi.org/10.1016/j.solener.2016.07.009

Skunpong, R., \& Plangklang, B. (2011). A practical method for quickly PV sizing. Procedia Engineering, 8, 120-127. https://doi.org/10.1016/j.proeng.2011.03.022

Solangi, K. H., Islam, M. R., Saidur, R., Rahim, N. A., \& Fayaz, H. (2011). A review on global solar energy 
policy. Renewable and Sustainable Energy Reviews. https://doi.org/10.1016/j.rser.2011.01.007

Unidad de Planeación Minero Energética. Ministerio de Minas y Energía UPME. Colombia. (2015). Proyección de la demanda de energía eléctrica y potencia máxima en Colombia (Marzo 2015).

UPME Unidad de Planeación Minero Energética. (2009). Plan de Expansión de Referencia Generación Transmisión 2009-2023. Unidad de Planeación Minero Energética UPME. ... Retrieved from http://scholar.google.com/scholar?hl=en\&btnG=Search\&q=intitle:Plan+de+Expansión+de+Referencia $+:+G$ eneración+Transmisión+2009-2023\#0

UPME, \& BID. (2015). Integración de las energías renovables no convencionales en Colombia. Ministerio de Minas y Energía. https://doi.org/10.1017/CBO9781107415324.004

Westwood, A., \& Hopwood, D. (2010). Offshore Wind and Marine Project Update: UK potential in focus. Renewable Energy Focus, 9(August 2008), 2010-2011.

Wiedman, J., \& Beach, T. (2013). Distributed generation policy: Encouraging generation on both sides of the meter. Electricity Journal, 26(8), 88-108. https://doi.org/10.1016/j.tej.2013.08.008

Willey, J., \& Sons. (2016). The Time Value of Money: Discounting and Net Present Values. In Lessons in Corporate Finance. Hoboken, NJ, USA (pp. 287-302). https://doi.org/10.1002/9781119228899.ch13

\section{Copyrights}

Copyright for this article is retained by the author(s), with first publication rights granted to the journal.

This is an open-access article distributed under the terms and conditions of the Creative Commons Attribution license (http://creativecommons.org/licenses/by/4.0/). 